\title{
Studies of gut mucosal protein synthesis in a non- steroidal anti-inflammatory drug (NSAID) model of inflammatory bowel disease
}

Department of Clinical Biochemistry, King's College School of Medicine and Dentistry, London

A K Banerjee

J S Marway

V R Preedy

T J Peters

Correspondence to: Dr Victor R Preedy, Biochemistry, King's College School of Medicine and Dentistry, Bessem
London SE5 9PJ.

Reprint requests to: Dr A K Banerjee at above address.

Accepted for publication 24 April 1991

\author{
A K Banerjee, J S Marway, V R Preedy, T J Peters
}

\begin{abstract}
The extent to which defects in protein synthesis occurred in an experimental indomethacin induced rat model of nonsteroidal enteropathy has been examined. Male rats (nine) were fed indomethacin $(8 \mathrm{mg} /$ $\mathrm{kg} /$ day) for three days mixed with a powdered form of chow. The control group of rats (nine) were fed the same diet for three days without indomethacin. After the feeding period, both groups were fed a normal solid diet for four days. At the end of this period, the fractional rates of intestinal protein synthesis was determined by the 'flooding dose' technique. The mucosal protein, RNA and DNA contents in the proximal ileum of animals with enteropathy were not significantly different from controls (p>0.05). Experimental enteropathy induced selective increases in the fractional rates of protein synthesis $(26 \%$ increase, $p<0.03)$ and RNA activities $(23 \%$ increase, $p<0.04)$. There were no significant changes in any of these variables in the duodenum $(p>0.05$ in all instances). These changes may partly reflect the activity of those processes responsible for the pathogenic changes in NSAID enteropathy.
\end{abstract}

Small bowel mucosal protein synthesis is of importance in inflammatory bowel disease for a variety of reasons. First, the pathogenesis of stricturing and, in NSAID enteropathy, submucosal diaphragms may well be the result of a differential imbalance in synthetic rates between gut structural proteins, collagen, and other stromal proteins, as well as mucosal soluble proteins. Second, the relationship between nutrition, body mass indices and small bowel mucosal absorptive function is important in inflammatory bowel disease. For example, many patients with inflammatory bowel disease are nutritionally compromised with enhanced nitrogen excretion and muscle wasting. The relationship between changes in mucosal proteins in the gastrointestinal tract and nutrient absorption in inflammatory bowel disease is, however, poorly understood. Third, recent work in cutaneous thermal injury in animals has shown increases in small gut paracellular permeability $^{1}$ and a reduction in small intestinal mucosal weight and nutrient absorption early in the postburn period. ${ }^{2}$ Furthermore, in this model, there were decreases in protein, RNA and DNA synthetic rates with the greatest effect in the jejunum. ${ }^{3}$ Potentially, factors initiating the acute inflammatory reaction may directly inhibit nucleic acid and protein synthesis and lead to alterations in nutrient absorption and intestinal barrier function in experimental indomethacin induced enteropathy.

For all these reasons a detailed characterisation of small intestine protein turnover was carried out in indomethacin induced enteropathy. An established and well documented technique using a 'flooding dose' of phenylalanine was used to measure protein synthesis. ${ }^{+}$ This method overcomes problems of precursor specific radioactivity and other errors arising from the breakdown of labelled protein that are encountered when tracer amounts of amino acids are used. ${ }^{5}$ This method has been used with effect in the study of small bowel protein synthesis in starvation, various surgical stress situations, such as, partial hepatectomy ${ }^{67}$ and metabolic toxicity studies - for example, ethanol. ${ }^{8}$

\section{Methods}

\section{ANIMALS AND CHEMICALS}

$\mathrm{L}\left[4-{ }^{3} \mathrm{H}\right]$ phenylalanine was obtained from Amersham International (Amersham, UK), and the other reagents were obtained from The Sigma Chemical Company Ltd (Poole, Dorset, UK). Male rats, Sprague Dawley strain, were obtained from an inhouse breeding colony at weaning, housed in a temperature controlled environment on a 12 hour light/dark cycle commencing at $0700 \mathrm{~h}$, and fed a commercial diet (Labsure, Manea, Cambridgeshire, UK) ad libitum until 140-160 g body weight was achieved. The rats were divided into two groups of equal mean body weight.

\section{EXPERIMENTAL PROTOCOL}

The experimental group of rats were fed indomethacin $(8 \mathrm{mg} / \mathrm{kg} /$ day $)$ for three days mixed in a powdered form with the laboratory chow. The control group of rats (nine) were fed the same diet for three days without indomethacin - that is, standard rat chow alone ad libitum. After the feeding period, both groups were fed normal solid diet for four days. As previously described, at the end of this period, the development of enteropathy is demonstrable by in vivo ${ }^{51} \mathrm{Cr}$ EDTA test administration by gavage. ${ }^{9}$ Experimental animals all have $>5 \%$ ingested dose of ${ }^{51} \mathrm{Cr}$ excreted in their urine, while controls have $<5 \%$ excreted. $^{9}$

Rats were injected with $\mathrm{L}\left[4-{ }^{3} \mathrm{H}\right]$ phenylalanine; $150 \mathrm{mmol} / \mathrm{l} ; 150 \mu \mathrm{mol} / 100 \mathrm{~g}$ body weight through a lateral tail vein. ${ }^{+}$At two and 10 minutes after injection of isotope, rats were decapitated (three and six, for rats killed at 
two and 10 minutes, respectively) and blood collected for subsequent extraction of plasma. Briefly, mucosa was dissected out from the duodenum and proximal ileum/terminal jejenum and placed into ice cold plastic tubes, weighed, and the mucosa frozen on solid $\mathrm{CO}_{2}$ and stored at $-70^{\circ} \mathrm{C}$.

After an initial precipitation with $0.2 \mathrm{~mol} / \mathrm{l}$ $\mathrm{HClO}_{4}$ (to obtain $\mathrm{S}_{\mathrm{i}}$, the specific activity of free phenylalanine after neutralisation), pellets were washed twice in $12-14 \mathrm{ml} 0.2 \mathrm{~mol} / 1 \mathrm{HClO}_{4}$. Protein pellets were then digested in $10 \mathrm{ml} 0.3$ $\mathrm{mol} / \mathrm{l} \mathrm{NaOH}$, and a sample was removed for protein and DNA determination. ${ }^{10}$ After reprecipitation of the protein with $2 \mathrm{~mol} / \mathrm{l}$ $\mathrm{HClO}_{4}$, tubes were spun and the supernatants used to measure RNA in the supernatant. ${ }^{12}$ Protein pellets were washed repeatedly (that is, eight times, $12-14 \mathrm{ml}$ each) in $0 \cdot 2 \mathrm{~mol} / 1 \mathrm{HClO}_{4}$. After heating the protein pellets in $3 \mathrm{ml} 6 \mathrm{~mol} / \mathrm{l}$ hydrochloric acid $\left(36\right.$ hours, $\left.105^{\circ} \mathrm{C}\right)$, the hydrolysates were dried in vacuo over solid $\mathrm{NaOH}$ and $\mathrm{P}_{2} \mathrm{O}_{5}$. The residue was suspended in citrate buffer $(1.5 \mathrm{~mol} / \mathrm{l} ; \mathrm{pH} 6.3)$ for determination of $S_{B}$, the specific radioactivity of phenylalanine in tissue protein. The specific radioactivity of free phenylalanine in plasma, $S_{p}$, was determined in the supernatant after precipitation of the proteins with $0.2 \mathrm{~mol} / 1$ perchloric acid and subsequent neutralisation with saturated tripotassium citrate. ${ }^{+}$Phenylalanine specific radioactivities in tissue, plasma and protein were converted to 2-phenylethylamine, and assayed by fluorimetry and radioactivity by scintillation spectrophotometry. ${ }^{4}$

Fractional rates of protein synthesis (defined as the percentage of tissue protein renewed each day by synthesis - that is, $k_{s}, \% /$ day) were calculated from the formula:

$$
\mathrm{k}_{\mathrm{s}}=\frac{\mathrm{S}_{\mathrm{B}} \times 100}{\overline{\mathrm{S}_{\mathrm{i}}} \times \mathrm{t}}(\% / \text { day })
$$

where ' $\overline{S_{i}}$ ' is the mean specific radioactivity of the free phenylalanine in acid supernatants of tissue homogenates during synthesis measurement (calculated from $S_{i}$ at two and 10 minutes

TABLE I Protein, RNA and DNA composition and rates of protein synthesis in the proximal ileal mucosa of control and enteropathic animals

\begin{tabular}{|c|c|c|c|c|}
\hline & Control & Enteropathic & $\%$ Change & pvalue \\
\hline \multicolumn{5}{|l|}{ Weights and tissue composition } \\
\hline Rat weight $(\mathbf{g})$ & $234(10)$ & $237(12)$ & +1 & 0.648 \\
\hline Tissue weight $/ 10 \mathrm{~cm}(\mathrm{mg})$ & $331(69)$ & $328(62)$ & -1 & 0.935 \\
\hline Total protein $(\mathrm{mg})$ & $35.9(8.4)$ & $34 \cdot 5(6 \cdot 7)$ & -4 & 0.752 \\
\hline Protein concentration $(\mathrm{mg} / \mathrm{g})$ & $108(4)$ & $105(4)$ & -3 & $0 \cdot 244$ \\
\hline Total RNA (mg) & $2 \cdot 29(0 \cdot 48)$ & $2 \cdot 24(0 \cdot 31)$ & -2 & 0.835 \\
\hline RNA concentration $(\mathrm{mg} / \mathrm{g})$ & $6.92(0.22)$ & $6.89(0.54)$ & 0 & 0.902 \\
\hline Total DNA (mg) & $2 \cdot 00(0 \cdot 20)$ & $2 \cdot 11(0.41)$ & +6 & 0.568 \\
\hline DNA concentration $(\mathrm{mg} / \mathrm{g})$ & $6 \cdot 23(1.34)$ & $6.59(1.61)$ & +6 & 0.683 \\
\hline \multicolumn{5}{|l|}{ Protein synthetic data } \\
\hline Intracellular specific activity $\left(\overline{S_{i}}, \mathrm{dpm} / \mathrm{nmol}\right)$ & $162(12)$ & $146(26)$ & -10 & $0 \cdot 204$ \\
\hline Plasma specific activity $\left(\mathrm{S}_{\mathrm{p}}, \mathrm{dpm} / \mathrm{nmol}\right)$ & $166(4)$ & $164(11)$ & -1 & 0.838 \\
\hline \multicolumn{5}{|l|}{ Terminal bound specific radioactivity $\left(S_{B}\right.$, } \\
\hline $\mathrm{dpm} / \mathrm{nmol})$ & $1 \cdot 48(0 \cdot 10)$ & $1 \cdot 64(0 \cdot 12)$ & +10 & 0.042 \\
\hline$k_{s}$ from $S_{i}(\% /$ day $)$ & $113(14)$ & $143(26)$ & +26 & 0.032 \\
\hline $\mathrm{k}_{\mathrm{s}}$ from $\overrightarrow{\mathrm{S}_{\mathrm{p}}}(\%$ /day $)$ & $110(7)$ & $125(16)$ & +13 & 0.064 \\
\hline $\mathrm{k}_{\mathrm{RNA}}$ from $\mathrm{S}_{\mathrm{i}}$ (g protein/day/g RNA) & $17 \cdot 6(2 \cdot 4)$ & $21 \cdot 7(3 \cdot 5)$ & +23 & 0.041 \\
\hline $\mathrm{k}_{\mathrm{RNA}}$ from $\mathrm{S}_{\mathrm{p}}(\mathrm{g}$ protein/day/g RNA) & $17 \cdot 1(0 \cdot 8)$ & $19 \cdot 0(1 \cdot 6)$ & +11 & 0.029 \\
\hline
\end{tabular}

All data are mean (SD), six observations in each group. Differences between means were assessed by Student's $t$ test for unpaired samples.

$S_{i}=$ specific radioactivity of free phenylalanine in acid supernatants of tissue homogenates. $S_{p}=$ specific radioactivity of free phenylalanine in plasma. $S_{B}=$ specific radioactivity of protein bound phenylalanine. $k_{\mathrm{s}}=$ fractional rates of protein synthesis. $\mathrm{k}_{\mathrm{RNA}}=\mathrm{RNA}$ activity. after injection of isotope), ' $S_{B}$ ' is the specific radioactivity of phenylalanine in the tissue protein at the end of the labelling period, and ' $t$ ' is the labelling time in days.

The above calculation assumes that proteins are labelled from free phenylalanine in the intracellular compartment. As there is no direct experimental evidence to support this, the $k_{s}$ was also calculated assuming that the free label in extracellular pools was incorporated into protein, ie by substituting $\overline{\mathrm{S}_{\mathrm{i}}}$ with $\overline{\mathrm{S}_{\mathrm{p}}}$ in the above formula, where $\overline{S_{p}}$. was the mean plasma specific radioactivity as determined from $S_{p}$ values in rats killed at two and 10 minutes. ${ }^{4}$

Rates of protein synthesis were also calculated in terms of RNA - that is, the RNA activity ( $k_{\text {RNA }}, g$ protein/day/g RNA), and were obtained by dividing $k_{S}$ by the RNA/protein ratios. ${ }^{67}$

\section{STATISTICAL ANALYSIS}

All data are shown as mean (SD) of six observations in each group. Differences between control and treated data were assessed by Student's unpaired $t$ tests (two tailed) with significance at the level of $p \leq 0.05$.

\section{Results}

\section{PROXIMAL ILEAL MUCOSA (TABLE I)}

The data are shown for both control and enteropathic animals seven days after the start of the experiment - that is, four days after cessation of indomethacin treatment. The rat weights, tissue weights, total mucosal proteins, and nucleic acid contents - that is, total amounts per $10 \mathrm{~cm}$, as well as protein and nucleic acid concentrations (amounts per unit wet weights) did not differ significantly between the groups. The mean $\overline{\mathrm{S}_{\mathrm{i}}}$ was reduced by $10 \%$ in enteropathic rats but this change was not significant $(p=0 \cdot 204)$. In contrast, the specific radioactivities of phenylalanine in proximal ileal proteins were increased (by approximately $10 \%$ ) as was $k_{s}$ calculated from $S_{i}$ (by 26\%). Translational efficiencies (amount of synthesis per unit RNA, $k_{\mathrm{RNA}}$ ) were also increased in enteropathic rats. Similar qualitative results were obtained when $k_{s}$ and $k_{R N A}$ were calculated from $\overline{S_{p}}$ (Table I).

The synthetic rates were corrected for the slight gradient of $S_{i}$ and $S_{p}$ between animals killed at two and 10 minutes. This acts as a methodological 'fail-safe' mechanism to correct for the decline in $S_{i}$ during the labelling period. ${ }^{45}$

DUODENAL MUCOSA (TABLE II)

Again, the tissue composition and protein synthetic rates are shown for both control and enteropathic animals four days after cessation of indomethacin treatment. There were no changes in protein, RNA or DNA composition. No significant differences were seen in any of the protein synthesis measurements between the two groups of animals (Table II).

\section{Discussion}

The results indicate that experimental indo- 
TABLE II Protein, DNA and RNA composition and rates of protein synthesis in the duodenal mucosa of control and enteropathic animals

\begin{tabular}{|c|c|c|c|c|}
\hline & Control & Enteropathic & $\%$ Change & p value \\
\hline \multicolumn{5}{|l|}{ Weights and tissue composition } \\
\hline Tissue weight $/ 10 \mathrm{~cm}(\mathrm{mg})$ & $414(55)$ & $410(66)$ & -1 & $0 \cdot 648$ \\
\hline Total protein $(\mathrm{mg})$ & $45 \cdot 8(6 \cdot 1)$ & $45 \cdot 2(7 \cdot 9)$ & -1 & $0 \cdot 886$ \\
\hline Protein concentration $(\mathrm{mg} / \mathrm{g})$ & $111(6)$ & $110(11)$ & 0 & 0.985 \\
\hline Total RNA (mg) & $2.90(0.42)$ & $2.94(0.48)$ & +1 & $0 \cdot 881$ \\
\hline RNA concentration $(\mathrm{mg} / \mathrm{g})$ & $7 \cdot 00(0 \cdot 28)$ & $7 \cdot 20(0 \cdot 77)$ & +3 & 0.563 \\
\hline Total DNA (mg) & $2.00(0.20)$ & $2 \cdot 11(0 \cdot 41)$ & +6 & 0.568 \\
\hline DNA concentration $(\mathrm{mg} / \mathrm{g})$ & $4.85(0.36)$ & $5 \cdot 15(0.57)$ & +6 & $0 \cdot 291$ \\
\hline \multicolumn{5}{|l|}{ Protein synthetic data } \\
\hline Terminal bound secific activity $\left(S_{B}, d p m / n m o l\right)$ & $1.61(0.15)$ & $1.60(0.06)$ & 0 & 0.947 \\
\hline$k_{s}$ from $\overline{S_{i}}(\% /$ day $)$ & $120(12)$ & $124(8)$ & +3 & 0.512 \\
\hline $\mathrm{k}_{\mathrm{s}}$ from $\mathrm{S}_{\mathrm{p}}(\% /$ day $)$ & $119(12)$ & $122(8)$ & +2 & 0.621 \\
\hline $\mathrm{k}_{\mathrm{RNA}}$ from $\mathrm{S}_{\mathrm{i}}$ (g protein/day/g RNA) & $19 \cdot 0(2 \cdot 4)$ & $19 \cdot 0(1 \cdot 2)$ & 0 & 1.00 \\
\hline $\mathrm{k}_{\mathrm{RNA}}$ from $\mathrm{S}_{\mathrm{p}}$ (g protein/day/g RNA) & $18 \cdot 9(2 \cdot 4)$ & $18 \cdot 7(1 \cdot 2)$ & -1 & $0 \cdot 859$ \\
\hline
\end{tabular}

All data are mean (SD), six per group. Experimental details are contained in the methods section and the legend to Table I. Differences between means were assessed by Student's $t$ test for unpaired samples. For abbreviations see Table I. some of the data of Carter et al. ${ }^{3}$ In their studies they did not determine the specific radioactivity of the free labelled amino acid during synthesis measurement. ${ }^{3}$ The interpretational errors arising from such techniques have been clearly described by the classical studies of Waterlow and colleagues (reviewed in ${ }^{5}$ ).

The mechanisms of the changes in protein synthesis in both indomethacin induced enteropathy (Table I) and thermal injury are complex; some of the changes in the latter may be prevented by the trophic hormone bombesin. ${ }^{15}$ There is some evidence that the changes seen with thermal injury are produced by intestinal ischaemia, as a result of injury-induced acute splanchnic vasoconstriction, ${ }^{16}$ although this is refuted by Jones et al. ${ }^{17}$

There is evidence that DNA synthesis may be at least partially dependent on protein synthesis in the small intestine, as shown by the use of cycloheximide in vivo. Verbin $e t a l^{18}$ have shown that drastic reductions in protein synthesis (such as an $80 \%$ reduction) eliminates DNA synthesis in the intestine. It is possible that protein synthesis is diminished by this degree in some selective regions of the intestinal mucosa, and that this directly inhibits DNA synthesis locally.

Our results indicate that protein degradation is increased in enteropathic ileal mucosa. Pertinent in this regard are studies on formylmethionyl-leucyl-phenylalanine (FMLP)induced ileitis in Sprague Dawley rats which suggest that neutrophils may cause mucosal damage by non-oxidative mechanisms involving enhanced proteolytic activity. ${ }^{1920}$ Von Ritter et $a l^{21}$ have shown in the FMLP ileitis model that the FMLP-induced increase in ${ }^{51} \mathrm{Cr}$ EDTA permeability is attenuated both by pre-treatment with soya bean trypsin inhibitor and post treatment with the specific elastase inhibitor Eglin C. Other evidence for altered proteolysis in the pathogenesis of the mucosal lesions observed in inflammatory bowel disease is controversial for example, normal or even decreased tissue mucosal levels of proteolytic enzymes. ${ }^{22} 23$

It is important to reemphasise the validity of our protein synthesis measurements for two reasons. First, the studies of Preedy and Peters ${ }^{24}$ recently showed that there was a lack of equilibration between the intracellular $\left(\mathrm{S}_{\mathrm{i}}\right)$ and extracellular $\left(S_{p}\right)$ pools of free labelled amino acids in rats chronically fed liquid diets containing ethanol or isocaloric glucose. ${ }^{24}$ In the present study there was an excellent equilibration between the extracellular and intracellular pools. In control and enteropathic rats the mean $S_{i} / S_{p}$ ratio in the proximal ileum was 0.98 and 0.89 , respectively. In the duodenum the corresponding $S_{i} / S_{p}$ values were 0.99 and 0.99 respectively. These values compare with a corresponding mean $S_{i} / S_{p}$ ratio of between 0.34 and 0.36 in the study of Preedy and Peters. ${ }^{24}$ Second, some studies have injected the isotope intraperitonally and used free and protein bound phenylalanine specific radioactivities at 15 minutes to calculate rates of protein synthesis in various tissues (see Jepson $e t a l)^{25}$ based on the assumptions that the rise of $S_{i}$ to plateau is rapid and unaffected by the experimental treatment being investigated. ${ }^{25} \mathrm{We}$ have recently shown, however, that the rise of ing the acute inflammatory reaction may dire inhibit nucleic acid and protein synthesis and lead to alterations in nutrient absorption and intestinal barrier function. The findings described in the present paper are analogous. Caution is required, however, in interpreting 
intestinal $\mathrm{S}_{\mathrm{i}}$ to plateau was significantly retarded by chronic ethanol toxicity. ${ }^{26}$ In the current study, we injected the isotope intravenously and killed rats at two and 10 minutes after the injection to accurately define the time course changes of $S_{i}$ and $S_{p}$. Therefore, we feel our present data to be reliable and accurate. Although $\mathrm{k}_{\mathrm{s}}$ in the proximal ileum was altered by approximately a quarter, and $p$ ranged from 0.03 to 0.04 , we consider this significant, and these observations may have profound physiological implications.

Anjan K Banerjee is in receipt of a MRC Research Fellowship and Jaspaul S Marway in receipt of a MRC Research Studentship.

1 Carter EA, Tompkins RG, Schiffrin E, Burke JF. Cutaneous thermal injury alters macro-molecular permeability of rat small intestine. Surgery 1990; 107: 335-41.

2 Mochizuki H, Trocki O, Dominioni L, Brackett KA, Joffe SN, Alexander JW. Mechanism of prevention of post-burn hypermetabolism and catabolism by early enteral feeding. Ann Surg 1984; 200: 297-310.

3 Carter EA, Hatz RA, Yarmush ML, Tompkins RG. Injuryinduced inhibition of small intestinal protein and nucleic acid synthesis. Gastroenterology 1984; 98: 1445-51.

4 Garlick PJ, McNurlan MA, Preedy VR. A rapid and conenient technique for measuring the rate of protein synthesis in tissues by injection of $\left[{ }^{3} \mathrm{H}\right]$ phenylalanine. Biochem 7 1980; 192: 719-23.

5 Waterlow JC, Garlick PJ, Millward DJ. Protein turnover in mammalian tissues and in the whole body. Amsterdam: North Holland, 1978.

6 Preedy VR, Paska L, Sugden PH, Schofield PS, Sugden MC. The effects of surgical stress and short-term fasting on protein synthesis in vitro in diverse tissues of the mature rat. Biochem 7 1988; 250: 179-88.

7 Preedy VR, Paska L, Sugden PH, Schofield PS, Sugden MC. Protein synthesis in liver and extra-hepatic tissues after partial hepatectomy. Biochem f 1990; 267: 325-30.

8 Preedy VR, Duane P, Peters TJ. Acute ethanol dosage reduces the synthesis of smooth muscle contractile proteins in the small intestine of the rat. Gut 1988; 29: 1244-8.

9 Banerjee AK, Peters TJ. NSAID enteropathy - similarities to inflammatory bowel disease and effect of thromboxane synthetase inhibitors. Gut 1990; 31: 1358-64.

10 Downs TR, Wilfinger WW. Fluorimetric quantification of DNA in cells and tissue. Anal Biochem 1983; 131: 538-47.

11 Gornall HG, Bardawill CI, David MM. Determination of serum proteins by means of the biuret reaction. $f$ Biol Chem 1949; 177: 751-66.

12 Munro HN, Fleck A. Analysis of tissues and body fluids for nitrogenous constituents. In: Munro HN, ed. Mammalian protein metabolism, vol 3. New York: Academic Press, 1969: 423-586.

13 Uribe A, Rubio C, Johansson C. Alternating proliferative capacity in the rat gastro-intestinal mucosa: effects of E2 prostaglandins and indomethacin. Scand f Gastroenterol 1988; 23: $163-70$.

14 Lang J, Price AB, Levi AJ, Burke M, Gumpel JM, Bjarnason I. Diaphragm disease: the pathology of non-steroidal antiinflammatory-induced small intestine strictures. F Clin inflammatory-induced smol $1988 ; 41: 516-26$.

15 Coffey JA, Milhoar RA, Abdullah A, et al. Bombesin inhibits bacterial translocation from the gut in burned rats. Surg Forum 1988; 39: 109-10

16 Morris SE, Navarathnam N, Townsend CM, Herndon DN Bacterial translocation and mesenteric blood flow in a large animal model after cutaenous thermal and smoke inhalation injury. Surg Forum 1988; 39: 189-90.

17 Jones WG, Minei JP, Barber AE, Fahey TJ, Shires GT, Shires $T$. Additive effects of thermal injury and infection on the small bowel. Surgery 1990; 108: 63-70.

18 Verbin RS, Liang H, Saeg LM, Diluiso G, Goldblatt PJ, Farber E. Effects of inhibitors of protein synthesis on Farber E. Effects of inhibitors of protein synthesis on Exp Cell Res 1971; 65: 81-93.

19 Von Ritter C, Sekizuka E, Grisham MB, Granger DN. The chemotactic peptide $\mathrm{N}$-formyl methionyl-leucylphenlalanine increases permeability in the distal ileum of the rat. Gastroenterology 1988; 95: 651-6.

20 Von Ritter C, Hollwarth M, Grisham MB, Granger DN. Role of oxygen-derived free radicals in FMLP-induced ileitis in rats. Gastroenterology 1988; 94: A625.

21 Von Ritter C, Be R, Granger DN. Neutrophilic proteases: mediators of formyl-methionyl-leucyl-phenylalanineinduced ileitis in rats. Gastroenterology 1989; 97: 605-9.

22 Kane SP, Vincenti AC. Mucosal enzymes in human inflammatory bowel disease with reference to neutrophil granulocytes tory bowel disease with reference to neutrophil granulocy

23 O'Morain C, Smethurst P, Levi AJ, Peters TJ. Biochemical analysis of enzymic markers of inflammation in rectal biopsies from patients with ulcerative colitis and Crohn' disease. F Clin Pathol 1983; 36: 1312-6.

24 Preedy VR, Peters TJ. Protein synthesis in muscle fractions from the small intestine in alcohol fed rats. Gut 1990; 31 305-10.

25 Jepson MM, Pell JM, Bates PC, Millward DJ. The effect of endotoxaemia on protein metabolism in skeletal muscle and liver of fed and fasted rats. Biochem 7 1986; 235: 329-6.

26 Preedy VR, Peters TJ. Changes in protein, RNA and DNA and rates of protein synthesis in muscle-containing tissues of and rates of protein synthesis in muscle-containing tissues of study of heart, small intestine and gastrocnemius muscle. Alcohol Alcohol 1990; 25: 489-98. 